\title{
Characteristics of coconut frond as a potential feedstock for biochar via slow pyrolysis
}

\author{
Nur Syairah Mohamad Aziz *, Adilah Shariff, Nurhayati Abdullah, Nurhidayah Mohamed Noor \\ Energy Studies Laboratory, School of Physics, Universiti Sains Malaysia, 11800, Pulau Pinang, Malaysia \\ *Corresponding author: syairahaziz_energyusm@yahoo.com
}

\section{Article history}

Submitted 2 February 2018

Revised 9 April 2018

Accepted 28 June 2018

Published Online 3 December 2018

\begin{abstract}
The aim of this study is to investigate the potential of coconut frond as a feedstock for biochar production via slow pyrolysis process. Proximate, elemental and thermogravimetric analysis were performed to evaluate the chemical and thermal properties of the coconut frond. The percentage of its lignocellulosic component and high heating value were determined. Surface morphology of coconut frond was examined using field emission scanning electron microscope (FESEM). Coconut frond (CF) contains $78.03 \pm 3.91$ d.b. wt $\%$ of volatile matter, $4.96 \pm 0.07$ d.b. wt $\%$ of ash content and $17.01 \pm 3.86$ d.b. wt $\%$ of fixed carbon. Elemental analysis revealed a sulfur content of $0.94 \pm 0.12 \%$, while the percentage of nitrogen is $0.46 \pm 0.33 \%$. The composition of carbon and hydrogen are $34.0 \pm 6.22 \%$ and $7.71 \pm 0.34 \%$ respectively. The high heating value of CF is $17.77 \pm 0.40 \mathrm{MJ} / \mathrm{kg}$. CF consists of $43.91 \pm 1.80 \%$ cellulose, $31.58 \pm 1.20 \%$ hemicellulose, and $18.15 \pm 0.60 \%$ lignin. From thermogravimetric $(\mathrm{TG})$ analysis, it is apparent that the weight loss of $\mathrm{CF}$ occurred prominently in the temperature range $200^{\circ} \mathrm{C}-400^{\circ} \mathrm{C}$. The peaks of the DTG curve at $281.75 \pm 0.35^{\circ} \mathrm{C}$ and $334.08 \pm 0.35^{\circ} \mathrm{C}$ indicate the weight loss of coconut frond sample due to the degradation of hemicellulose and cellulose, respectively. The FESEM images of CF show its fibrous strands are compact with a few large pores with diameters around $42.5-48.1 \mu \mathrm{m}$ large pores in the center of the CF sample. The results of the analysis show that CF has a potential as a feedstock for biochar production via slow pyrolysis. CF also can be used in other application such as syngas and bio-oil production due to the low lignin percentage and high volatile percentage.
\end{abstract}

Keywords: Biomass, coconut frond, feedstock, properties

\section{INTRODUCTION}

Fossil fuel consumption has increased the concentration of carbon dioxide $\left(\mathrm{CO}_{2}\right)$ in the atmosphere. About $98 \%$ of carbon emissions result from fossil fuel combustion (Demirbas, 2005). The $12^{\text {th }}$ annual Global Carbon Budget estimates the global carbon emissions from fossil fuels will rise significantly by $2 \%$ by the end of 2017 (Carrington, 2017). World Meteorological Organization reported that the global average concentration of $\mathrm{CO}_{2}$ has reached 403 parts per million (ppm) in 2016, compared to $400 \mathrm{ppm}$ in the previous year due to a strong $\mathrm{El}$ Nino event and the human activities such as deforestation and industrialisation (Watts, 2017; World Meteorological Organization, 2017). $\mathrm{CO}_{2}$ is one of the greenhouse gases besides methane $\left(\mathrm{CH}_{4}\right)$ and nitrous oxide $\left(\mathrm{N}_{2} \mathrm{O}\right)$, which cause global warming. The rise of sea level, an increase in the intensity of extreme weather and significant changes to the amount and pattern of precipitation are among the consequences of global warming. According to National Oceanic and Atmospheric Administration (NOAA), global sea level in 2014 was 2.6 inches above the highest annual average record since 1993 and it continues to rise at a rate of about one-eighth of an inch per year (NOAA, 2017). As the energy supplies are mainly based on the fossil fuel resources such as coal, oil and natural gas, the concerns on the depleting natural resources and the consequences of climate change and energy security should be fully addressed.

Renewable energy has been identified as the world's fastestgrowing energy resource, increasing by an average $2.3 \%$ per year between 2015 and 2040 (US Department of Energy, 2017). Biomass is known as one of the major world renewable energy resources.
Generally, biomass refers to forestry, purpose-grown agricultural crops, trees and plants, and organic, agricultural, agro-industrial and domestic wastes such as municipal and solid waste (Demirbas \& Arin, 2002). Usually, biomass such as agricultural waste is not disposed of properly. In many countries, agricultural waste such as stalks, leaves, and husks are burned to reduce the residues from the agricultural activities (CEC, 2014).

The coconut tree, Cocos nucifera is a member of the palm family Arecaceae. It is grown for different purposes in various parts of the world. About 12 million ha of land are cultivated around the world with 60 million tonnes production reported for the year 2014 (FAO, 2017). Ninety percent of global coconut supply comes from Asia region (McAloon, 2017). Indonesia is the largest producer of coconut in the world with more than 18 million tonnes production, while Malaysia remains as one of the top 10 of producing countries in the world (Yon, 2016). The increment of coconut production and expansion of coconut plantation area will lead to the higher residues generation from the industry.

The residues generated from the coconut industry include husk, shell, frond, and residual coconut fiber, which could be obtained after the extraction of coconut milk. Meanwhile, coconut frond and trunk are the common residues generated at coconut plantations. Usually, coconut farmers dispose of the residues in the coconut plantation by burning or leaving it to rot in the fields. To some extent, burning can help to kill pest while in-situ composting can stimulate soil microbial activity and nutrient cycling. However, excessive burning activity is harmful to the environment. The burning process leads to air pollution 
and soil erosion while the accumulation of residues on the ground could cause a phytosanitary problem (Tomas, 2013).

According to a report by Raghavan (2010), the global total production of coconut biomass including the kernel but excluding the coconut water is about 106 million tonnes and $60.5 \%$ of them are unprocessed. In South East Asia and the Asia Pacific alone, the estimated annual waste is around 25 million tons (DP CleanTeach, 2017). Hence, the utilization of biomass especially coconut wastes as feedstock for chemicals and energy products could reduce the abundance of agricultural waste which usually lead to waste management problems.

The production and application of biochar have gained much attention due to its promising benefits and function in addressing the environmental problems. It is has been promoted as a tool for climate change mitigation because, in soil application, it is expected to sequester carbon for thousand years and help in reducing greenhouse gases emission from soils (Brassard et al., 2016).

Biochar is a solid material obtained from thermochemical conversion of biomass in an oxygen-limited environment. According to Lehmann \& Joseph (2015), it can be used for a range of applications such as an agent for soil enhancement, improved resource use efficiency, remediation or protection against particular environmental pollution and as an avenue for greenhouse gases (GHG) mitigation. Works of literature reported that biochar has potentials to be applied as a soil amendment (Khalifa \& Yousef, 2015) and activated carbon (Ahiduzzaman \& Sadrul Islam, 2016). High carbon content and good adsorption capacity are the important properties in soil application and carbon sequestration. Meanwhile, high carbon content and high surface area are necessary for the utilization of biochar as activated carbon (Mahmood et al., 2015).

There have been few papers that studied the utilization of coconut frond as feedstock. Coconut fronds have been used to produce activated carbon for the adsorption of carbofuran insecticide (Njoku et al., 2014). However, the properties of CF feedstock was not reported. Sharif et al. (2016) studied the properties of coconut fronds (CF) and coconut husk $(\mathrm{CH})$ feedstocks and the effect of slow pyrolysis temperature on biochar yield. It was reported that $\mathrm{CF}$ is a suitable feedstock for slow pyrolysis. They also found that the percentage yield of $\mathrm{CF}$ biochar was lower compared to biochar yield of $\mathrm{CH}$, due to lower lignin composition.

The properties of biochar are greatly influenced by the characteristics of feedstock used. The data from the preliminary analysis of feedstock such as proximate, elemental and thermogravimetric analysis will provide useful information on feedstock behaviour during thermochemical conversion. The data also can be used in the prediction of biochar properties. For example, the feedstock with high carbon and lignin content will produce a high yield of biochar with high carbon content. Therefore, the objective of this paper is to study the properties of coconut fronds as a potential feedstock for biochar production. The understanding of the properties of feedstock will help in enhancing the quality of biochar produced

\section{EXPERIMENTAL}

\section{Materials}

Coconut frond samples were collected from a plantation in Butterworth, Pulau Pinang. The samples were collected from the fallen $\mathrm{CF}$, which were found under the coconut trees in the plantation. Then, the fronds were cut into smaller pieces as shown in Figure 1. The CF was then dried in a conventional oven (Venticell 222-Standard) at $105^{\circ} \mathrm{C}$ until the moisture content was below $10 \mathrm{wt} \%$ to avoid the growth of fungi or mould. The CF was ground to pass a $600 \mu \mathrm{m}$ sieve and then stored in an airtight container prior to analysis.

Proximate analysis was carried out in accordance with ASTM E871 (ASTM, 2006a), ASTM E872 (ASTM, 2006b) and ASTM E1755-01 (ASTM, 2007) for moisture content (MC), volatile matter (VM) and ash content (AC) respectively. Fixed carbon was determined from the calculation as shown in Equation (1). The results of the proximate analysis were expressed on a dry basis (d.b. wt\%).

$$
F C(\text { d.b. } w t \%)=100-V M-A C
$$

Elemental analysis was performed to determine the percentage of carbon $(\mathrm{C})$, hydrogen $(\mathrm{H})$, nitrogen $(\mathrm{N})$ and sulfur $(\mathrm{S})$ in $\mathrm{CF}$ using an elemental analyzer (Perkin Elmer 2400). The percentage of oxygen composition in $\mathrm{CF}$ is obtained from equation (2):

$$
\text { Oxygen }(\%)=100-C-H-N-S-A C
$$

Lignin and $\alpha$-cellulose content of CF were determined according to ASTM D1106-96 (ASTM, 2013a) and ASTM D1103-60, (ASTM, 1977) respectively. The percentage of holocellulose was determined according to ASTM D1104-56 (ASTM, 1978). Then, the percentage of hemicellulose was determined from the difference between holocellulose and cellulose percentages (Li, 2004). Each analysis was performed in triplicate.

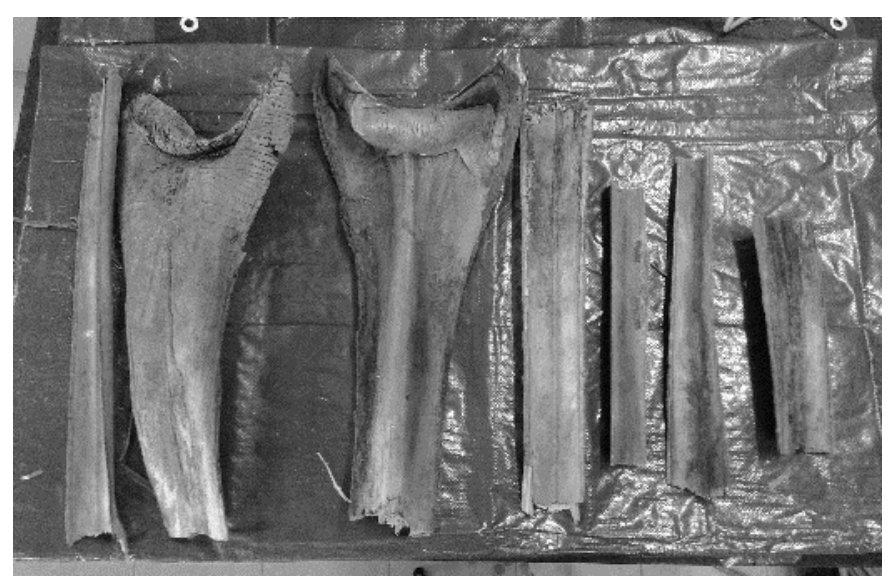

Fig. 1 Coconut frond sample.

The thermal study was done on the coconut frond sample by performing thermogravimetric (TG) analysis using a Mettler Toledo TG Analyzer. Five mg of ground CF sample was weighed and placed into the sample pan and heated from $30^{\circ} \mathrm{C}$ to $900^{\circ} \mathrm{C}$ at a heating rate of $10^{\circ} \mathrm{C} / \mathrm{min}$ under a continuous nitrogen flow of $30 \mathrm{ml} / \mathrm{min}$. This analysis was done in duplicate.

The higher heating value (HHV) of CF sample was determined using a bomb calorimeter (IKA C200). This analysis was carried out by placing $0.5 \mathrm{~g}$ of ground CF into a crucible and subsequently transferred inside a stainless steel container. The decomposition vessel was filled with 30 bar of oxygen and ignited through a cotton thread connected to a solid ignition wire inside the decomposition vessel and burned. This bomb calorimeter is validated in accordance with ASTM D5865-13 (ASTM, 2013b). This analysis was also done in duplicate.

The surface morphology of CF was examined using a field emission scanning electron microscope (FESEM) from FEI Nova NanoSEM 450. Approximately $7.5 \mathrm{mg}$ of CF were attached to the stub and then placed on the stub holder inside the specimen chamber. The FESEM was operated at $10 \mathrm{kV}$. The image of the sample was displayed on the connecting monitor.

\section{RESULTS AND DISCUSSION}

Table 1 shows the result of proximate analysis of the CF. It contains 7.08 d.b. wt $\%$ of moisture, 78.03 d.b. wt $\%$ of VM, an AC of 4.96 d.b. wt\% and 17.01 d.b. wt\% of FC. The high VM content in the CF is needed for autothermal pyrolytic conversion of CF to biochar (Rahman et al., 2004). The ash content of CF in this study is higher compared to the other coconut residues such as coconut shell and coconut husk that contain about 0.7 d.b. wt $\%$ and 0.33 d.b. wt $\%$ of $\mathrm{AC}$ respectively (Tsamba et al., 2006; Shariff et al., 2016). The high AC of CF might be due to the frond being on the ground before collection. 
Table 1 Proximate analysis of CF and other biomass.

\begin{tabular}{|c|c|c|c|c|c|}
\hline & Reference & MC & VM & $A C$ & FC \\
\hline $\begin{array}{l}\mathrm{CF} \\
\text { (d.b. wt\%) }\end{array}$ & This study & $\begin{array}{c}7.08 \pm \\
0.35\end{array}$ & $\begin{array}{l}78.03 \\
\pm 3.91\end{array}$ & $\begin{array}{c}4.96 \\
\pm 0.0 \\
7\end{array}$ & $\begin{array}{l}17.01 \\
\pm 3.86\end{array}$ \\
\hline $\begin{array}{l}\text { CF } \\
\text { (d.b. } \\
\text { wt\%) }\end{array}$ & $\begin{array}{l}\text { (Shariff et } \\
\text { al., 2016) }\end{array}$ & 0.37 & 89.96 & 4.67 & 5.37 \\
\hline $\begin{array}{l}\text { OPF } \\
\text { (d.b. wt\%) }\end{array}$ & $\begin{array}{l}\text { (Mahmood } \\
\text { et al., } \\
2015 \text { ) }\end{array}$ & 6.00 & 80.90 & 1.10 & 18.10 \\
\hline
\end{tabular}

In Table 1, the results of the proximate analysis are also compared with existing literature of CF feedstock (Shariff et al., 2016) and oil palm frond (OPF) (Mahmood et al., 2015) to gain a better understanding on the feedstock properties. The properties of $\mathrm{CF}$ in this study were found to be similar to OPF in terms of the VM and FC compositions. Meanwhile, the AC of OPF was found to be lower than $\mathrm{CF}$. This could be due to the condition of OPF and CF during the sample collection. The sample in this study was collected from the fallen $\mathrm{CF}$ on the ground. The AC of CF in this study is almost similar to the $\mathrm{CF}$ feedstock reported by Shariff et al. (2016). However, it could be observed that the percentage of VM in this study is lower than reported by Shariff et al. (2016). This could be due to the species variations and cultivation conditions of the samples.

From the proximate analysis of biomass feedstock, we could estimate the percentage of AC, FC, and VM of biochar. Previous studies (Noor et al., 2012; Shariff et al., 2014; Kabir et al., 2017) reported that $\mathrm{FC}$ and $\mathrm{AC}$ of derived biochar would be higher compared to the percentage in the feedstock. Meanwhile, the percentage of VM of biochar would be lower due to the release of volatiles from the breaking of weaker bridges and bonds in organic matrices (Pechyen et al., 2007). Therefore, it could be expected that the biochar derived from feedstock with higher FC and AC percentage will have a higher composition of AC and FC. However, the biochar yield percentage could not be estimated from the data of proximate analysis solely as it also depends on the percentage of lignocellulose composition.

The properties of the feedstock in Table 1 are plotted in Figure 2 presents the mean proximate composition of various biomass and solid fuels reported by Vassilev et al. (2010). The similarities among different groups of biomass feedstock could be observed clearly in this triangle. The properties of $\mathrm{CF}$ in this study have intermediate positions between woody biomass and herbaceous-agricultural biomass.

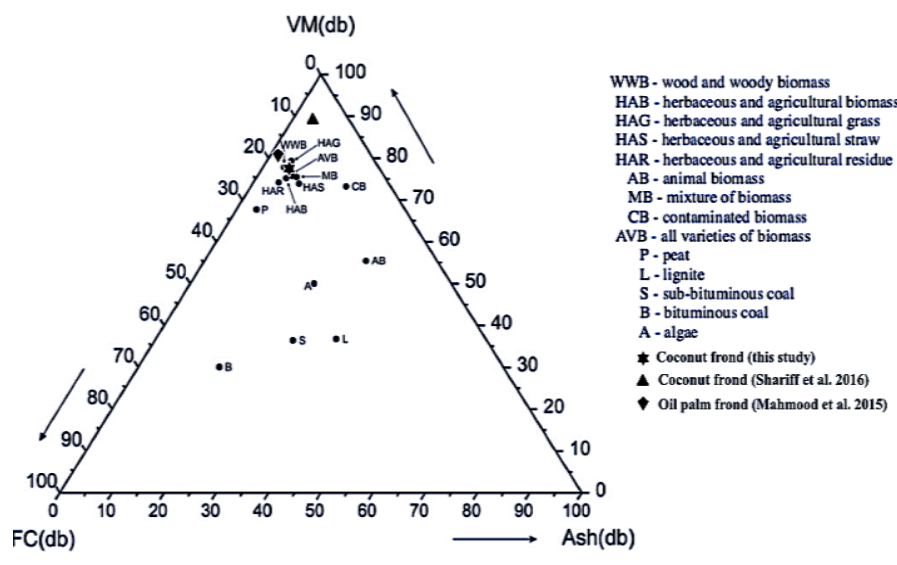

Fig. 2 Mean proximate composition of various biomass and solid fuels. Adapted from Vassilev (2010).

Elemental composition of CF is presented in Table 2 in dry ash-free basis. Coconut fronds contain $34.01 \%$ of carbon, $7.71 \%$ of hydrogen and $51.92 \%$ of oxygen. It can be observed that $\mathrm{CF}$ contains a very small amount of sulfur and nitrogen, $0.94 \%$ and $0.46 \%$ respectively. The low percentage of sulfur and nitrogen in $\mathrm{CF}$ will make it safe to be used as feedstock for slow pyrolysis process.
CF contains $31.58 \%$ of hemicellulose, $43.91 \%$ of cellulose and $18.15 \%$ of lignin. Cellulose is identified as the major component of CF. Cellulose degrades to a more stable anhydrocellulose, which produce higher biochar yield and is the dominant reaction at a temperature less than $302^{\circ} \mathrm{C}(575 \mathrm{~K})$ (Shafizadeh, 1985). Meanwhile, at a higher temperature, cellulose depolymerizes and produces volatiles (Demirbas, 2006). Lignin composition in the CF also contributes to the formation of char. In contrast, lignin slowly degrades over a wide range of temperature (Lee et al., 2013). Compared to other biomass such as coconut shell and OPF (Table 2), it can be observed that the percentage of lignin of $\mathrm{CF}$ is the lowest. Therefore, $\mathrm{CF}$ feedstock is also recommended for the production of syngas and bio-oil.

The lignocellulosic component plays significant roles in the determination of biomass behaviour during slow pyrolysis and the yield percentage of the products; biochar, bio-oil and syngas. According to $\mathrm{Qu}$ et al. (2011), the pyrolysis product distribution is possible to be predicted according to the lignocelllulosic component proportion in a biomass as these three components have very different thermal behaviours. For example, biomass feedstock with high lignin content usually will produce higher char yield since lignin is preferentially converted to char during pyrolysis (Sun et al., 2012).

However, the percentage of lignin composition is not the only influencing factor (Gómez et al., 2016). Previous studies (Eom et al., 2011; Qu et al., 2011; Shariff et al., 2014) reported that the percentage of inorganic matter such as ash also influences the percentage of biochar yield. Generally, feedstock with higher ash percentage will produce higher biochar yield. High ash in the feedstock acts as a catalyst to promotes secondary reactions of primary pyrolysis products, which further degrade to secondary tars, char and gases (Abdullah \& Bridgwater, 2006; Ronsse, 2016).

Table 2 Properties of CF and other biomass.

\begin{tabular}{|c|c|c|c|c|}
\hline Sample & $\begin{array}{c}\text { Coconut } \\
\text { Frond }\end{array}$ & $\begin{array}{l}\text { Coconut } \\
\text { Frond }\end{array}$ & $\begin{array}{c}\text { Coconut } \\
\text { Shell }\end{array}$ & $\begin{array}{l}\text { Oil Palm } \\
\text { Frond }\end{array}$ \\
\hline Reference & This study & $\begin{array}{l}\text { (Shariff et } \\
\text { al., 2016) }\end{array}$ & $\begin{array}{c}\text { (Cagnon et } \\
\text { al., 2009) }\end{array}$ & $\begin{array}{l}\text { (Kabir et } \\
\text { al., 2017) }\end{array}$ \\
\hline \multicolumn{5}{|l|}{$\begin{array}{l}\text { Elemental } \\
\text { composition } \\
\text { (daf \%) }\end{array}$} \\
\hline Carbon & $34.01 \pm 6.22$ & 42.81 & 48.70 & 41.0 \\
\hline Hydrogen & $7.71 \pm 0.34$ & 7.23 & 5.80 & 6.74 \\
\hline Nitrogen & $0.46 \pm 0.33$ & 0.00 & 0.30 & 0.67 \\
\hline Sulfur & $0.94 \pm 0.12$ & 0.77 & 0.30 & 0.35 \\
\hline Oxygen & $51.92 \pm 5.44$ & 44.52 & 42.2 & 45.37 \\
\hline $\begin{array}{l}\text { Empirical } \\
\text { formula }\end{array}$ & $\begin{array}{c}\mathrm{CH}_{2.70} \mathrm{~N}_{0.01} \mathrm{O}_{1} \\
.15\end{array}$ & $\begin{array}{c}\mathrm{CH}_{2.01} \mathrm{~N}_{0.0 .0} \\
\mathrm{O}_{0.86}\end{array}$ & $\begin{array}{c}\mathrm{CH}_{1.42} \mathrm{~N}_{0.01} \\
\mathrm{O}_{0.62}\end{array}$ & $\begin{array}{c}\mathrm{CH}_{1.96} \mathrm{~N}_{0.01} \\
\mathrm{O}_{0.83}\end{array}$ \\
\hline \multicolumn{5}{|l|}{$\begin{array}{l}\text { Ligno- } \\
\text { cellulosic } \\
\text { composition } \\
(\%)\end{array}$} \\
\hline Hemicellulose & $31.58 \pm 1.20$ & 22.49 & 35.00 & 19.22 \\
\hline Cellulose & $43.91 \pm 1.80$ & 39.05 & 15.00 & 45.22 \\
\hline Lignin & $18.15 \pm 0.60$ & 21.46 & 50.00 & 31.24 \\
\hline HHV (MJ/kg) & $17.77 \pm 0.40$ & $\mathrm{n} / \mathrm{a}$ & $\mathrm{n} / \mathrm{a}$ & 16.0 \\
\hline HHV (MJ/kg)* & 19.0 & $\mathrm{n} / \mathrm{a}$ & $\mathrm{n} / \mathrm{a}$ & 17.63 \\
\hline
\end{tabular}

$\mathrm{n} / \mathrm{a}$ : not available

*predicted using equation from Parikh et al. (2005)

The properties of the CF used in this study are also compared with the properties of $\mathrm{CF}$, coconut shell (CS) and OPF reported in the literature as shown in Table 2. CF was found to have lower lignin content compared to coconut shell and OPF. As lignin contribution is higher than cellulose and hemicellulose contribution in the generation of char (Gupta et al., 2016), it could be expected that the char yield of $\mathrm{CF}$ will be lower than that of coconut shell and OPF under same pyrolysis conditions.

The result of higher heating value (HHV) of CF feedstock is also presented in Table 2. The higher heating value (HHV) of the CF is $17.77 \mathrm{MJ} / \mathrm{kg}$. It is higher than the HHV of OPF reported by Kabir et al. (2017). The HHV value also could be predicted using equation 
$\mathrm{HHV}=0.3536 \mathrm{FC}+0.1559 \mathrm{VM}-0.0078 \mathrm{AC}$ as reported by Parikh et al. (2005). The predicted values of HHV are also presented in Table 2 and agree reasonably well with experimental data. The characterization of the heating value of biomass feedstock is necessary for energy analysis and numerical simulations of the thermochemical conversion system (Sheng \& Azevedo, 2005; Nhuchhen \& Abdul Salam, 2012).

It could be observed that the elemental properties of $\mathrm{CF}$ are almost similar to OPF compared to the other coconut wastes. In terms of lignocellulosic composition, it could be observed that cellulose is the main component for both $\mathrm{CF}$ and OPF. CF has lower carbon composition compared to coconut shell and OPF. It is also lower than the percentage of carbon reported by Shariff et al. (2016). This could be due to few factors such as the variations of species, geographic origin and fertilizer treatment (Jones et al., 2014). CF contains higher hydrogen and oxygen composition compared to other biomass in Table 2. A van Krevelen diagram (plot of $\mathrm{H} / \mathrm{C}$ versus $\mathrm{O} / \mathrm{C}$ atomic ratios in daf basis) of $\mathrm{CF}$ feedstock and other biomass is presented in Fig. 3. It was observed that the CF feedstock was not fallen within the cluster of herbaceous crops, which represented by mischantus gigantus and switchgrass. The ratios $\mathrm{CF}$ feedstock also did not fall near the OPF, CF and cellulose. The low percentage of $\mathrm{C}$ of $\mathrm{CF}$ feedstock found in this study could be one of the reasons of the deviation of $\mathrm{H} / \mathrm{C}$ and $\mathrm{O} / \mathrm{C}$ ratios of $\mathrm{CF}$ compared to the ratios reported from the works of literature.

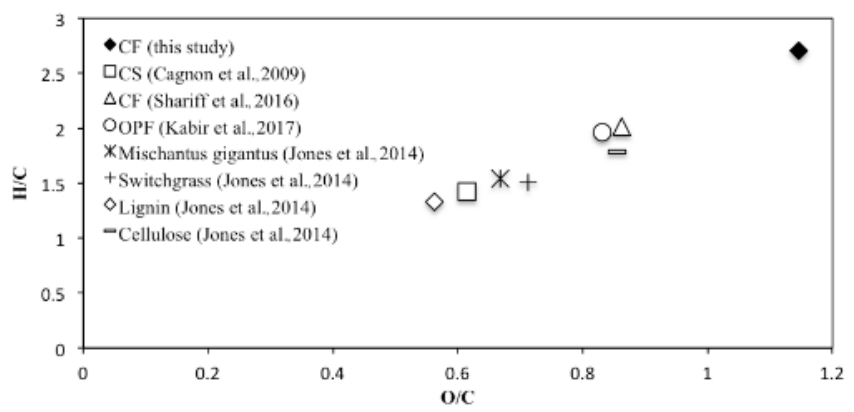

Fig. 3 Van Krevelen plot of CF, lignin, cellulose and other biomass.

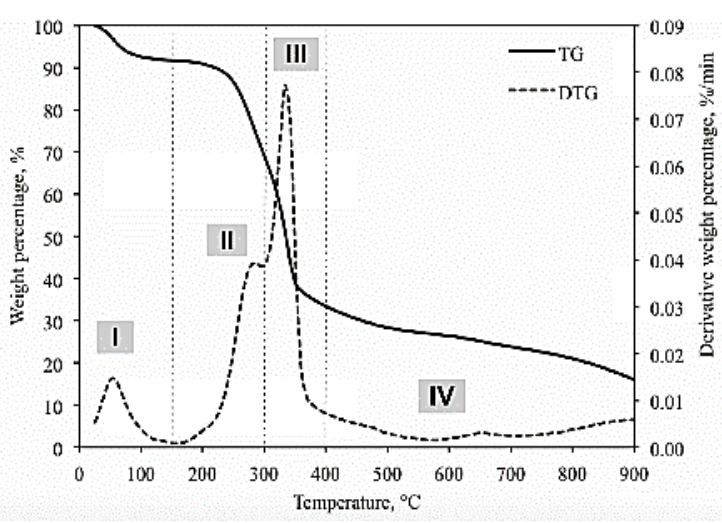

Fig. 4 TG and DTG curves of coconut frond sample.

The result of TG analysis of CF is shown in Figure 4. The TG curve indicates the fractional weight loss of feedstock as a function of temperature. The derivative TG (DTG) curve presented the rate of weight change versus temperature. The result from TG analysis could be used to detail the main steps of biomass conversion (Collard \& Blin, 2014).

The weight loss of the feedstock sample at a temperature below $100^{\circ} \mathrm{C}$ was found to be $7.32 \mathrm{wt} \%$ and attributed to moisture loss. A similar MC was obtained using the conventional method (Table 1). However, the weight within $100^{\circ} \mathrm{C}$ to $200^{\circ} \mathrm{C}$ changed only by $1.6 \%$. The weight loss of $\mathrm{CF}$ is prominent within the temperature range $200^{\circ} \mathrm{C}$ to $400^{\circ} \mathrm{C}$ amounting to about $60 \%$. Weight loss of $\mathrm{CF}$ decreases gradually beyond $400^{\circ} \mathrm{C}$. According to the TG plot in Figure 4, it is estimated that around $17-33 \mathrm{wt} \%$ of char yield can be achieved by the pyrolysis of $\mathrm{CF}$ at a temperature beyond $400^{\circ} \mathrm{C}$. Fan et al. (2017) achieved higher char yield from the coconut shell sample, around 20$40 \mathrm{wt} \%$ due to higher lignin content of coconut shell sample.

In Figure 4, it can be clearly observed that the peaks of the DTG curve exist at three different temperatures. To discuss the relationship between peaks on the DTG curve and the weight loss, the thermal degradation of CF has been divided into four regions, I-IV as shown in Figure 3. Region I is for the temperature up to $150^{\circ} \mathrm{C}$ accounting for the removal of moisture from $\mathrm{CF}$. Region II is for the temperature range $150^{\circ} \mathrm{C}-300^{\circ} \mathrm{C}$. A distinct peak could be observed at $281^{\circ} \mathrm{C}$ indicating the degradation of hemicellulose and certain lignin components in the CF. According to Yang et al. (2004), the degradation of hemicellulose occurs within the temperature range $220^{\circ} \mathrm{C}-300^{\circ} \mathrm{C}$. Region III shows a large peak at $333^{\circ} \mathrm{C}$. The formation of this peak could be explained by the degradation of cellulose and partial lignin. Cellulose component in biomass usually degrades within the temperature range $300^{\circ} \mathrm{C}$ $340^{\circ} \mathrm{C}$, while the degradation of lignin starts at around $340^{\circ} \mathrm{C}$ (Yang et al., 2004). No DTG peak could be observed in region IV. Beyond $400^{\circ} \mathrm{C}$, no high peak could be observed and both TG and DTG curves are gradual. This is due to the degradation of lignin, which is distributed along a wide range of temperature, and its peak is not commonly distinguishable ( $\mathrm{Li}$ et al. 2008). In addition, weight loss in this region could be attributed to in-char structure rearrangement besides the lignin decomposition with an occasional transformation of ash (Fan et al., 2017).

The data from the TG analysis also can be used to determine the minimum temperature for the pyrolysis process of the feedstock. From Figure 4, it can be observed that the weight loss of CF gradually decreases after $400^{\circ} \mathrm{C}$ and no significant peaks could be observed beyond this temperature. Therefore, $400{ }^{\circ} \mathrm{C}$ can be determined as minimum pyrolysis temperature for $\mathrm{CF}$ feedstock to produce biochar.

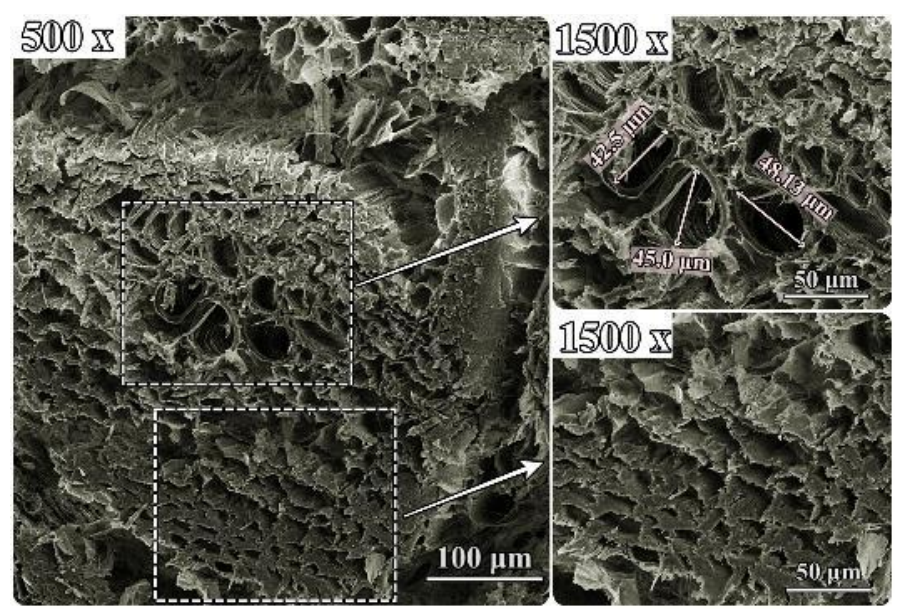

Fig. 5 FESEM image of coconut frond sample.

Figure 5 shows the FESEM image of CF. At 500x magnification, the cross section of $\mathrm{CF}$ shows that it consists of fibrous strands. It can be observed that most of the fibrous strands of $\mathrm{CF}$ are compact. As the image was magnified by $1500 x$, it can be clearly observed that the fibrous strands in the bottom part are more compact compared to the middle part of CF sample where a few pores could be observed. The diameters of the pores in the middle part of $\mathrm{CF}$ raw feedstock are around $42.5-48.1 \mu \mathrm{m}$. These pores are larger than the diameter of clay, root hair and fungi, which has a diameter around 2-5 $\mu \mathrm{m}, 2-10 \mu \mathrm{m}$ and 15-17 $\mu \mathrm{m}$ respectively. The pores could be developed and further enhanced by the chemical activation during the course of pyrolysis as reported by Tsai et al. (2001). The pore size could be increased by several thousand folds depends on the pyrolysis temperature as well as the properties of feedstock (Thies et al., 2015).

In soil application, the porous structure of biochar could provide a habitat for microbes to colonize, grow and reproduce, particularly once biochar is aged in soil (Thies et al., 2015). However, the biochar also could provide a habitat for bacteria or toxins harmful to the plant, which will result in a negative outcome of biochar application (Howard, 2011). The overall effect of biochar as soil enhancer may be influenced 
by the type of microbes in the soil, type of soil or sand as well as the kind of plant used.

\section{CONCLUSION}

Previous studies have reported the production of biochar from different types of biomass such as empty fruit bunches (Shariff et al., 2014), oil palm frond (Kabir et al.,, 2017), rice husk (Gupta et al., 2016) and cassava wastes (Noor et al. 2012). The properties of CF are revealed in this study. It was shown that $\mathrm{CF}$ has a high potential as a feedstock for biochar production via a thermochemical process such as slow pyrolysis. CF contains 78.03 d.b. wt $\%$ volatile matter. The ash and fixed carbon contents of CF are 4.96 d.b. wt $\%$ and 17.01 d.b. wt $\%$ respectively. $\mathrm{CF}$ is an environmental friendly feedstock for slow pyrolysis due to its very low percentage of nitrogen and sulfur contents. CF contains $34.01 \%$ carbon, $7.71 \%$ hydrogen and $51.92 \%$ oxygen. The high heating value of $\mathrm{CF}$ is $17.77 \mathrm{MJ} / \mathrm{kg}$. CF consists of $43.91 \%$ cellulose, $31.58 \%$ hemicellulose and $18.15 \%$ lignin. The weight loss of coconut frond sample was found to be prominent between $200^{\circ} \mathrm{C}$ and $400^{\circ} \mathrm{C}$. The DTG peaks of TG analysis at $281^{\circ} \mathrm{C}$ and $333^{\circ} \mathrm{C}$ indicate the degradation of hemicellulose and cellulose respectively. FESEM images show that the fibrous strands are compact and a few pores can be seen in the center of the CF sample. It is evident from the properties of $\mathrm{CF}$ that $\mathrm{CF}$ is a suitable feedstock that can be used for producing biochar via slow pyrolysis.

\section{ACKNOWLEDGEMENT}

The authors wish to express their gratitude to the Universiti Sains Malaysia for the technical support and Ministry of Higher Education (MOHE) Malaysia for financing this research through the Fundamental Grant Research Scheme (FRGS: 203/PFIZIK/6711410).

\section{REFERENCES}

Abdullah, N., \& Bridgwater, A. V. 2006. Pyrolysis liquid derived from oil palm empty fruit bunches. Journal of Physical Science 17(2): 117-129.

Ahiduzzaman, M., \& Sadrul Islam, A. K. M. 2016. Preparation of porous biochar and activated carbon from rice husk by leaching ash and chemical activation. SpringerPlus 5(1): 1248.

ASTM. 1977. Method of Test for Alpha Cellulose in Wood D1103-60. United States: ASTM International.

ASTM. 1978. Method of Test for Holocellulose in Wood D1104-56. United States: ASTM International.

ASTM. 2006a. Standard test method for moisture analysis of particulate wood fuels E871-82. New York: ASTM International.

ASTM. 2006b. Standard test method for volatile matter in the analysis of particulate wood fuels E872-82. United States: ASTM International.

ASTM. 2007. Standard test method for ash in biomass E1755-01. United States: ASTM International.

ASTM. 2013a. Standard test method for acid-insoluble lignin in wood D110696. United States: ASTM International.

ASTM.2013b. Standard Test Method for gross calorific value of coal and coke D5865-13. United States: ASTM International.

Brassard, P., Godbout, S., \& Raghavan, V. 2016. Soil biochar amendment as a climate change mitigation tool: Key parameters and mechanisms involved. Journal of environmental management 181(Supplement C): 484-497.

Cagnon, B., Py, X., Guillot, A., Stoeckli, F., \& Chambat, G. 2009. Contributions of hemicellulose, cellulose and lignin to the mass and the porous properties of chars and steam activated carbons from various lignocellulosic precursors. Bioresource Technology 100(1),: 292-298.

Carrington, D. 2017. Fossil fuel burning set to hit record high in 2017, scientists warn.

https://http://www.theguardian.com/environment/2017/nov/13/fossilfuel-burning-set-to-hit-record-high-in-2017-scientists-warn November 2017].

CEC. 2014. Burning agricultural waste: A source of dioxins. Montreal, Canada Fact sheet from Commissions for Environmental Cooperation.

Demirbas, A. 2005. Potential applications of renewable energy sources, biomass combustion problems in boiler power systems and combustion related environmental issues. Progress in Energy and Combustion Science 31(2): 171-192.
Collard, F.-X., \& Blin, J. 2014. A review on pyrolysis of biomass constituents: Mechanisms and composition of the products obtained from the conversion of cellulose, hemicelluloses and lignin. Renewable and Sustainable Energy Reviews 38: 594-608.

Demirbas, A. 2006. Production and characterization of bio-chars from biomass via pyrolysis. Energy Sources, Part A: Recovery, Utilization, and Environmental Effects 28(5): 413-422.

Demirbas, A., \& Arin, G. 2002. An overview of biomass pyrolysis. Energy Sources 24(5): 471-482.

DP CleanTeach. 2017. Understanding coconut as a biomass fuel http://www.dpcleantech.com/download-file/2017-06-07-00-44-14pdf [21 November 2017].

Eom, I.-Y., Kim, K.-H., Kim, J.-Y., Lee, S.-M., Yeo, H.-M., Choi, I.-G., \& Choi, J.-W. 2011. Characterization of primary thermal degradation features of lignocellulosic biomass after removal of inorganic metals by diverse solvents. Bioresource Technology 102(3): 3437-3444.

Fan, Y., Fowler, G. D., \& Norris, C. 2017. Potential of a pyrolytic coconut shell as a sustainable biofiller for styrene-butadiene rubber. Industrial \& Engineering Chemistry Research 56(16): 4779-4791.

FAO. 2017. Crops Statistic. http://www.fao.org/faostat/en/ - data/QC [22 November 2017].

Gómez, N., Rosas, J. G., Cara, J., Martínez, O., Alburquerque, J. A., \& Sánchez, M. E. 2016. Slow pyrolysis of relevant biomasses in the Mediterranean basin. Part 1. Effect of temperature on process performance on a pilot scale. Journal of Cleaner Production 120: 181-190.

Gupta, N. K., Prakash, P., Kalaichelvi, P., \& Sheeba, K. N. 2016. The effect of temperature and hemicellulose-lignin, cellulose-lignin, and cellulosehemicellulose on char yield from the slow pyrolysis of rice husk. Energy Sources, Part A: Recovery, Utilization, and Environmental Effects 38(10): 1428-1434.

Howard, T. 2011. The effect of biochar on the root development of corn and soybeans in minnesota soil and sand. Retrieved from http://www.biocharinternational.org/sites/default/files/T_Howard_Scienc e_Paper.pdf [20 May 2018].

Jones, J. M., Lea-Langton, A. R., Ma, L., Pourkashanian, M., \& Williams, A. 2014. Combustion of solid biomass: Classification of fuels. In Pollutants Generated by the Combustion of Solid Biomass Fuels, pp. 9-24. London: Springer London.

Kabir, G., Mohd Din, A. T., \& Hameed, B. H. 2017. Pyrolysis of oil palm mesocarp fiber and palm frond in a slow-heating fixed-bed reactor: A comparative study. Bioresource Technology 241(Supplement C): 563-572.

Khalifa, N., \& Yousef, L. F. 2015. A short report on changes of quality indicators for a sandy textured soil after treatment with biochar produced from fronds of date palm. Energy Procedia 74: 960-965.

Lee, Y., Park, J., Ryu, C., Gang, K. S., Yang, W., Park, Y.-K., Jung, J., Hyun, S. 2013. Comparison of biochar properties from biomass residues produced by slow pyrolysis at $500{ }^{\circ} \mathrm{C}$. Bioresource Technology $148(0)$ : 196-201.

Lehmann, J., \& Joseph, S. 2015. Biochar for environmental management: An introduction. In J. Lehmann \& S. Joseph (ed.), Biochar for Environmental Management Science, Technology and Implementation Second Edition, pp. 1-14. New York: Routledge.

Li, W., Yang, K., Peng, J., Zhang, L., Guo, S., \& Xia, H. 2008. Effects of carbonization temperatures on characteristics of porosity in coconut shell chars and activated carbons derived from carbonized coconut shell chars. Industrial Crops and Products 28(2): 190-198.

Li, X. 2004. Physical, chemical, and mechanical properties of bamboo and its utilization potential for fiberboard manufacturing. MSc Thesis. Louisiana State University, Baton Rouge, LA

Mahmood, W. M. F. W., Ariffin, M. A., Harun, Z., Ishak, N., Ghani, J. A., \& Ab Rahman, M. N. 2015. Characterisation and potential use of biochar from gasified oil palm wastes. Journal of Engineering Science and Technology 10 (Spec. Issue on 4th International Technical Conference (ITC) 2014): 45-54.

McAloon, C. 2017. Coconut faces a looming global supply shortage, but could an Australian industry crack it. http://www.abc.net.au/news/rural/201708-26/australians-love-coconuts-so-should-we-grown-our-own/8834012 [21 November 2017].

Nhuchhen, D. R., \& Abdul Salam, P. 2012. Estimation of higher heating value of biomass from proximate analysis: A new approach. Fuel 99: 55-63.

Njoku, V. O., Islam, M. A., Asif, M., \& Hameed, B. H. 2014. Preparation of mesoporous activated carbon from coconut frond for the adsorption of carbofuran insecticide. Journal of Analytical and Applied Pyrolysis 110(0): 172-180

Noor, N.M., Shariff, A., \& Abdullah, N., 2012. Slow pyrolysis of cassava wastes for biochar production and characterization. Iranica Journal of Energy and Environment (IJEE) 3: 60-65.

NOAA. 2017. Is sea level rising? https://oceanservice.noaa.gov/ facts/sealevel.html [21 November 2017]. 
Parikh, J., Channiwala, S. A., \& Ghosal, G. K. 2005. A correlation for calculating HHV from proximate analysis of solid fuels. Fuel 84(5): 487494.

Pechyen, C., Atong, D., Aht-Ong, D., \& Sricharoenchaikul, V. 2007. Investigation of pyrolyzed chars from physic nut waste for the preparation of activated carbon. Journal of Solid Mechanics and Materials Engineering 1(4): 498-507.

Qu, T., Guo, W., Shen, L., Xiao, J., \& Zhao, K. 2011. Experimental study of biomass pyrolysis based on three major components: hemicellulose, cellulose, and lignin. Industrial \& Engineering Chemistry Research 50(18): 10424-10433.

Raghavan, K. 2010. Biofuels from coconuts. Wageningen, Netherlands.

Rahman, A. A., Abdullah, N., \& Sulaiman, F. 2014. Temperature effect on the characterization of pyrolysis products from oil palm fronds. Advances in Energy Engineering 2(1): 14-21.

Ronsse, F. 2016. Biochar Production. In V. J. Bruckman, E. A. Varol, B. B. Uzun, \& J. Liu (ed.). Biochar: A Regional Supply Chain Approach in View of Climate Change Mitigation, pp. 199-226. Cambridge, United Kingdom: Cambridge University Press.

Shafizadeh, F. 1985. Pyrolytic reactions and products of biomass. In Overend, R. P., Milne, T. A. \& Mudge, L. K. (ed.), Fundamentals of Thermochemical Biomass Conversion, pp. 183-217. Dordrecht: Springer Netherlands.

Shariff, A., Aziz, N. S. M., \& Abdullah, N. 2014. Slow pyrolysis of oil palm empty fruit bunches for biochar production and characterization. Journal of Physical Science 25(2): 97-112.

Shariff, A., Aziz, N. S. M., Salleh, N. M., \& Ruzali, N. S. I. 2016. The effect of feedstock type and slow pyrolysis temperature on biochar yield from coconut wastes. International Journal of Chemical, Molecular, Nuclear, Materials and Metallurgical Engineering 10(12): 1361-1365.

Sheng, C., \& Azevedo, J. L. T. 2005. Estimating the higher heating value of biomass fuels from basic analysis data. Biomass and Bioenergy, 28(5): 499-507.

Sun, H., Hockaday, W. C., Masiello, C. A., \& Zygourakis, K. (2012). Multiple controls on the chemical and physical structure of biochars. Industrial \& Engineering Chemistry Research 51(9): 3587-3597.

Thies, J. E., Rillig, M. C., \& Graber, E. R. 2015. Biochar effects on the abundance, activity and diversity of the soil biota. In J. Lehmann \& S. Jospeh (ed.), Biochar for Environmental Management: Science, Technology and Implementation Second Edition, pp. 327-389. New York: Routledge.

Tomas, U.-G. J. 2013. Recycling of waste coconut shells as substitute for aggregates in mix proportioning of concrete hollow blocks. WSEAS Transactions on Environment and Development 9(4): 290-300.

Tsai, W. T., Chang, C. Y., Lee, S. L., \& Wang, S. Y. 2001. Thermogravimetric analysis of corn cob impregnated with zinc chloride for preparation of activated carbon. Journal of Thermal Analysis and Calorimetry 63(2): 351-357.

Tsamba, A. J., Yang, W., \& Blasiak, W. 2006. Pyrolysis characteristics and global kinetics of coconut and cashew nut shells. Fuel Processing Technology 87(6): 523-530.

US Department of Energy. 2017. International Energy Outlook 2017. https://http://www.eia.gov/outlooks/ieo/ [19 September 2017].

Vassilev, S. V., Baxter, D., Andersen, L. K., \& Vassileva, C. G. 2010. An overview of the chemical composition of biomass. Fuel 89(5): 913-933.

Watts, J. 2017. Global atmospheric CO2 levels hit record high https://http://www.theguardian.com/environment/2017/oct/30/globalatmospheric-co2-levels-hit-record-high [21 November 2017].

World Meteorological Organization. 2017. Greenhouse gas concentrations surge to new record. https://public.wmo.int/en/media/press-release/greenhousegas-concentrations-surge-new-record [22 November 2017].

Yang, H., Yan, R., Chin, T., Liang, D. T., Chen, H., \& Zheng, C. 2004 Thermogravimetric analysis-fourier transform infrared analysis of palm oil waste pyrolysis. Energy \& Fuels 18(6): 1814-1821.

Yon, R. 2016. Revival of coconut industry in Malaysia. http://ap.fftc.agnet.org/files/ap_policy/806/806_1.pdf [21 November 2017]. 